\title{
Photochemical efficiency of basil cultivars fertigated with salinized nutrient solutions
}

\author{
Sandy T. dos Santos ${ }^{1}$, Francisco de A. de Oliveira ${ }^{1}$, Giordanio B. S. Oliveira ${ }^{1}$, Francisco V. da S. Sá ${ }^{1}$, \\ Jessilanne P. B. de M. Costa ${ }^{1} \&$ Pedro D. Fernandes ${ }^{2}$
}

${ }^{1}$ Universidade Federal Rural do Semi-Árido/Centro de Ciências Agrárias, Mossoró, RN, Brasil. E-mail: sandy_thomaz@hotmail.com - ORCID: 00000001-6487-555X; thikaoamigao@bol.com.br (Corresponding author) - ORCID: 0000-0002-6895-7736; giordaniobruno1@gmail.com - ORCID: 00000001-5418-7171; vanies_agronomia@hotmail.com - ORCID: 0000-0001-6585-8161; jessilannyplinia@hotmail.com - ORCID: 0000-0002-1023-7154

${ }^{2}$ Universidade Federal de Campina Grande/Centro de Tecnologia e Recursos Naturais/Unidade Acadêmica de Engenharia Agrícola, Campina Grande, PB, Brasil. E-mail: pedrodantasfernandes@gmail.com - ORCID: 0000-0001-5070-1030

\begin{abstract}
Reduction in plant growth under salt stress is due, among other factors, to changes in photochemical efficiency and, consequently, in photosynthesis. The objective of this study was to evaluate the effect of salt stress on the chlorophyll fluorescence variables in cultivars of basil (Ocimum basilicum L.). The experiment was conducted in a greenhouse, using a randomized block design in a $5 \times 3$ factorial scheme, corresponding to five basil cultivars ('Grecco a Palla', 'Alfavaca Basilicão', 'Alfavaca Verde,' 'Lemoncino' and 'Roxo') and three salinity of the nutrient solution (2.0, 3.5 and $\left.5.0 \mathrm{dS} \mathrm{m}^{-1}\right)$, with three repetitions, and the experimental plot was represented by three pots containing $3.0 \mathrm{dm}^{3}$ of coconut fiber. At the full flowering stage, plants were evaluated for chlorophyll fluorescence, when adapted to the dark, as well as under saturating light conditions. In general, there were changes in fluorescence variables only at salinity above $3.5 \mathrm{dS} \mathrm{m} \mathrm{m}^{-1}$. Fertigation using high-salinity water promotes strong changes in the chlorophyll a fluorescence of sensitive basil cultivars. The cultivars 'Grecco a Palla' and 'Alfavaca Verde' were little affected by the increase of salinity, being the most tolerant to salt stress. In the cultivars 'Alfavaca Basilicão', 'Lemoncino' and 'Roxo', chlorophyll fluorescence was strongly affected by salinity, being the most sensitive. The tolerance ranking based on chlorophyll fluorescence is: 'Grecco a Palla' = 'Alfavaca Verde' > 'Alfavaca Basilicão' > 'Lemoncino' > 'Roxo.'
\end{abstract}

Key words: Ocimum basilicum L., medicinal plants, salt stress, chlorophyll fluorescence, photosynthesis

\section{Eficiência fotoquímica de cultivares de manjericão fertigada com soluções nutritivas salinizadas}

RESUMO: A redução do crescimento das plantas sob estresse salino é decorrente, entre outros fatores, de alterações na eficiência fotoquímica, e consequentemente na fotossíntese. Com isto, objetivou-se avaliar o efeito do estresse salino sobre as variáveis da fluorescência da clorofila em cultivares de manjericão (Ocimum basilicum L.). O experimento foi conduzido em casa de vegetação, seguindo o delineamento experimental de blocos casualizados, em esquema fatorial 5 x 3, sendo cinco cultivares de manjericão ('Grecco a Palla', 'Alfavaca Basilicão', 'Alfavaca Verde,' 'Lemoncino' e 'Roxo') e três salinidades da solução nutritiva (2,0; 3,5 e 5,0 $\mathrm{dS} \mathrm{\textrm {m } ^ { - 1 }}$, com três repetições, sendo a parcela experimental representada por três vasos contendo $3,0 \mathrm{dm}^{3} \mathrm{de}$ fibra de coco. Na fase de pleno florescimento as plantas foram avaliadas quanto à fluorescência da clorofila, quando adaptadas ao escuro, como também em condições de luz saturante. De forma geral, houve alterações nas variáveis da fluorescência apenas em salinidade acima de $3,5 \mathrm{dS} \mathrm{m} \mathrm{m}^{-1}$. A fertigação usando água de alta salinidade promove fortes alterações na fluorescência da clorofila a das cultivares sensíveis de manjericão. As cultivares 'Grecco a Palla' e 'Alfavaca Verde' foram pouco afetadas pelo aumento da salinidade, sendo as mais tolerantes ao estresse salino. As cultivares 'Alfavaca Basilicão', 'Lemoncino' e 'Roxo' tiveram a fluorescência da clorofila fortemente afetada pelo efeito da salinidade, sendo as mais sensíveis. O ranque de tolerância com base na fluorescência da clorofila é: 'Grecco a Palla' = 'Alfavaca Verde' > 'Alfavaca basilicão' > 'Lemoncino' > 'Roxo'.

Palavras-chave: Ocimum basilicum L., plantas medicinais, estresse salino, fluorescência da clorofila, fotossíntese 


\section{INTRODUCTION}

Basil (Ocimum basilicum L.), also known in Portuguese as 'alfavaca', 'alfavaca -cheirosa', 'basílico', 'alfavaca doce', 'erva real', 'manjericão doce', is a plant belonging to the Lamiaceae family, widely used in folk medicine and as condiment and seasoning (Palaretti et al., 2015). In the year of 2017, 3,913 t of basil were produced in Brazil, $47 \mathrm{t}$ of which in the state of Rio Grande do Norte (IBGE, 2019).

The crop adapts to the wide climatic conditions and its growth is favored in regions of hot climate, which enables cultivation throughout the year (Favorito et al., 2011). Its cultivation has recently been studied in protected environment, mainly in hydroponic system (Bione et al., 2014; Menezes et al., 2017).

In the hydroponic system, the quality of the water used to prepare the nutrient solution, regarding the content of salts, is a factor of great importance, because the use of saline water $\left(\mathrm{ECw}>3.5 \mathrm{dS} \mathrm{m}^{-1}\right)$ can cause reductions in plant growth and yield, although there are differences between species regarding the tolerance to nutrient solution salinity (Martins et al., 2019; Rosas et al., 2019; Silva Júnior et al., 2019; Soares et al., 2019). Basil is classified as tolerant or moderately tolerant to salinity, showing slight reduction of growth under salinity of $5.0 \mathrm{dS} \mathrm{m}^{-1}$ (Attia et al., 2009); however, this level of tolerance depends on numerous factors, especially on the genotype (Maia et al., 2017; Menezes et al., 2017).

The reduction in plant growth and yield under salt stress conditions results from physiological changes, especially in the photosynthetic process, due to alterations in photochemical efficiency (Penella et al., 2014; Taibi et al., 2016), and these changes may be used as a tool for selecting salinity-tolerant genotypes (Azevedo Neto et al., 2011; Silva et al., 2014).

In view of the above, the objective of this study was to evaluate the effect of salt stress on the photochemical efficiency of chlorophyll in basil cultivars.

\section{Material ANd Methods}

The experiment was carried out from July 2018 to September 2018, in a greenhouse, without control of environmental conditions, located in the Departamento de Ciências Agronômicas e Florestais ( $5^{\circ} 12^{\prime}$ 4" S, 37 19' 39” W, average altitude of $18 \mathrm{~m}$ ), at the Centro de Ciências Agrárias of the Universidade Federal Rural do Semiárido (UFERSA), in Mossoró, Rio Grande do Norte, Brazil.

The experimental design used was randomized blocks, in $5 \times 3$ factorial scheme, with three repetitions and, as plot, three plants cultivated in $3-\mathrm{L}$ pots containing coconut fiber as substrate. The factors were composed by the combination of five cultivars ('Grecco a Palla', 'Alfavaca Basilicão', 'Alfavaca Verde', 'Lemoncino' and 'Roxo') with three salinity of the nutrient solutions ( $\mathrm{S} 1$ - standard nutrient solution $\left(2.0 \mathrm{dS} \mathrm{m}^{-1}\right)$, $\mathrm{SN}$; $22-\mathrm{SN}+0.68 \mathrm{~g} \mathrm{~L}^{-1}$ of $\mathrm{NaCl}\left(3.5 \mathrm{dS} \mathrm{m}^{-1}\right) ; \mathrm{S} 3-\mathrm{SN}+1.55 \mathrm{~g}$ $\mathrm{L}^{-1}$ of $\mathrm{NaCl}\left(5.0 \mathrm{dS} \mathrm{m} \mathrm{m}^{-1}\right)$.

The nutrient solutions were prepared using water from the UFERSA campus supply system, whose chemical analyses showed the following characteristics: $\mathrm{pH}=8.30 ; \mathrm{EC}=0.50 \mathrm{dS}$ $\mathrm{m}^{-1} ; \mathrm{Ca}^{2+}=3.10 ; \mathrm{Mg}^{2+}=1.10 ; \mathrm{K}^{+}=0.30 ; \mathrm{Na}^{+}=2.30 ; \mathrm{Cl}^{-}=1.80$; $\mathrm{HCO}_{3}=3.00$ and $\mathrm{CO}_{3}{ }^{2-}=0.20\left(\mathrm{mmol}_{\mathrm{c}} \mathrm{L}^{-1}\right)$. In order to obtain the solutions with the other salinity levels (S2 and S3), sodium chloride $(\mathrm{NaCl})$ was added to the water of lowest salinity $(0.5$ $\mathrm{dS} \mathrm{m}^{-1}$ ), and the levels were adjusted with the aid of a digital benchtop conductivity meter (TEC-4MP,Tecnal ${ }^{\circ}$ ).

Planting was carried out with seedlings propagated by seeds in expanded polystyrene trays with 128 cells, using substrate formulated by the mixture of earthworm humus and coconut fiber (1:1.5). The trays were irrigated every day using a watering can with very narrow holes, until the seedlings had three to four true leaves; after that, plants were transplanted to 3-L plastic containers, by placing one plant in each pot.

The pots were distributed inside the greenhouse and placed on top of three wooden benches with the following dimensions: $0.5 \mathrm{~m}$ high, $1.0 \mathrm{~m}$ wide and $5.0 \mathrm{~m}$ long, covered with black plastic film. Each bench had 45 pots arranged in three rows with 15 pots each, at spacing of $0.45 \mathrm{~m}$ between rows and 0.35 $\mathrm{m}$ between plants.

The irrigation system adopted was the drip system, using microtube emitters, which were previously evaluated under normal operating conditions, with emitters attached to the irrigation lines (polyethylene tubes). Each nutrient solution was applied using an independent irrigation system, formed by a Metalcorte/Eberle self-venting, circulation motor pump, model EBD250076, actuated by single-phase motor with 210 $\mathrm{V}$ voltage and $60 \mathrm{~Hz}$ frequency, one reservoir (60-L water tank), 16-mm-diameter hoses and microtubes with average flow rate of $2.78 \mathrm{~L} \mathrm{~h}^{-1}$.

The standard nutrient solution was the recommendation of Furlani et al. (1999) for leafy vegetables, containing the following amounts of fertilizers, in $\mathrm{g} 1000 \mathrm{~L}^{-1}$ : 750, 500, 150 and $400 \mathrm{~g}$ of $\mathrm{Ca}\left(\mathrm{NO}_{3}\right)_{2}, \mathrm{KNO}_{3}, \mathrm{MAP}$ and $\mathrm{MgSO}_{4}$, respectively. Micronutrients were supplied using the fertilizer Rexolim:

Fertigation began to be applied one day after transplanting, using the same doses of nutrients for all treatments, differentiating only in the amount of $\mathrm{NaCl}$ added to the reservoirs. The control was carried out through a timer (Digital Timer, TE-2 model, Decorlux ) adopting the frequency of six daily irrigations and adjusting the time of each irrigation according to the need of the crop. The nutrient solution volume consumed by plants was not determined; however, a volume sufficient to cause drainage was applied in each irrigation event.

Preventive phytosanitary control was periodically performed, with organic insecticide at dose of $2.0 \mathrm{~mL} \mathrm{~L}^{-1}$ (Tarssus green).

When plants reached full flowering, chlorophyll a fluorescence was evaluated using an Opti Science OS5p pulse-modulated fluorometer. For that, plants were dark adapted for $30 \mathrm{~min}$ and, subsequently, initial fluorescence $\left(\mathrm{F}_{0}\right)$, maximum fluorescence $\left(\mathrm{F}_{\mathrm{m}}\right)$, variable fluorescence $\left(\mathrm{F}_{\mathrm{v}}=\right.$ $\left.\mathrm{F}_{\mathrm{m}}-\mathrm{F}_{0}\right)$ and maximum quantum efficiency of PSII $\left(\mathrm{F}_{\mathrm{v}} / \mathrm{F}_{\mathrm{m}}\right)$ were determined (Silva et al., 2014). Also with the pulse-modulated fluorometer, applying an actinic light source with saturating multi-flash pulse, the electron transport rate (ETR), effective quantum efficiency of photosystem II (Y), non-photochemical dissipation or quantum yield of regulated dissipation (YNPQ) and non-regulated photochemical dissipation or quantum 
yield of non-regulated dissipation (YNO) were determined, following the methodology of Kramer et al. (2004).

The obtained data were subjected to analysis of variance, with further analysis of the factors when a significant response to the interaction between factors occurred. Treatment effects were analyzed by means comparison test (Tukey, $\mathrm{p} \leq 0.05$ ). Statistical analyses were carried out using the statistical software Sisvar version 5.6 (Ferreira, 2014).

\section{Results AND Discussion}

Initial fluorescence $\left(\mathrm{F}_{0}\right)$, maximum fluorescence $\left(\mathrm{F}_{\mathrm{m}}\right)$, variable fluorescence $\left(\mathrm{F}_{\mathrm{v}}\right)$, electron transport rate (ETR), effective quantum efficiency of PSII (Y) and non-photochemical dissipation (YNPQ) were significantly influenced by the interaction between cultivar and irrigation water salinity $(\mathrm{p} \leq$ 0.01 ), and YNPQ was significantly affected at $p \leq 0.05$. The nonregulated photochemical dissipation (YNO) was significantly affected by the single factors cultivars and salinity $(\mathrm{p}<0.05)$, while the maximum quantum efficiency of PSII $\left(\mathrm{F}_{\mathrm{v}} / \mathrm{F}_{\mathrm{m}}\right)$ was significantly affected only by salinity $(\mathrm{p} \leq 0.01)$ (Table 1$)$.

Significant interaction between salt stress and cultivars has also been observed by other authors working with different species of agronomic interest, such as basil (Mancarella et al., 2016), sesame (Dias et al., 2018) and cowpea (Oliveira et al., 2018), among others, demonstrating that chlorophyll fluorescence can be used to select salt stress-tolerant cultivars.

No significant difference was observed in $\mathrm{F}_{0}$ among cultivars in the absence of $\mathrm{NaCl}$, with an average $\mathrm{F}_{0}$ of 759.93 electrons quantum ${ }^{-1}$. The increase in nutrient solution salinity from 2.0 to $3.5 \mathrm{dS} \mathrm{m}^{-1}$ did not affect the initial fluorescence of the basil cultivars, but the cultivar 'Lemoncino' obtained higher values compared to 'Grecco a Palla'; however, these cultivars did not differ from the others. At the highest salinity level (5.0 dS $\mathrm{m}^{-1}$ ), there was reduction in the $\mathrm{F}_{0}$ of the cultivars 'Roxo' and 'Lemoncino', in comparison to the salinity of $2.0 \mathrm{dS} \mathrm{m}^{-1}$, and the cultivar 'Roxo' had the lowest values of initial fluorescence, in relation to the other cultivars studied (Table 2 ).

The reduction of initial fluorescence observed in the cultivar 'Roxo' under salt stress demonstrates the occurrence of structural changes in photosynthetic pigments, thus compromising the efficiency of the excitation energy from the light-harvesting antenna and damage to the PSII reaction centers (Baker, 2008). A probable explanation for such reduction is the decrease in the concentrations of photosynthetic pigments in plant leaves, which may be
Table 2. Initial fluorescence $\left(\mathrm{F}_{0}\right)$, maximum fluorescence $\left(\mathrm{F}_{\mathrm{m}}\right)$, variable fluorescence $\left(\mathrm{F}_{\mathrm{v}}\right)$ and maximum quantum efficiency of photosystem II $\left(\mathrm{F}_{\mathrm{v}} / \mathrm{F}_{\mathrm{m}}\right)$ of basil cultivars subjected to different nutrient solution salinity

\begin{tabular}{|c|c|c|c|c|}
\hline \multirow{2}{*}{ Cultivar } & \multicolumn{3}{|c|}{ Salinity } & \multirow{2}{*}{ Mean } \\
\hline & S1 & S2 & S3 & \\
\hline \multicolumn{5}{|c|}{$\mathrm{F}_{0}$} \\
\hline Grecco a Palla & $712.00 \mathrm{Aa}$ & $707.00 \mathrm{Ab}$ & $694.00 \mathrm{Aa}$ & 704.33 \\
\hline Alfavaca Basilicão & $766.67 \mathrm{Aa}$ & 801.33 Aab & $803.33 \mathrm{Aa}$ & 790.44 \\
\hline Alfavaca Verde & $758.67 \mathrm{Aa}$ & 875.67 Aab & $797.00 \mathrm{Aa}$ & 810.44 \\
\hline Lemoncino & $823.00 \mathrm{ABa}$ & $962.66 \mathrm{Aa}$ & $741.67 \mathrm{Ba}$ & 842.44 \\
\hline Roxo & $739.33 \mathrm{Aa}$ & $846.00 \mathrm{Aab}$ & $414.00 \mathrm{Bb}$ & 666.44 \\
\hline Mean & 759.93 & 838.53 & 690.00 & \\
\hline \multicolumn{5}{|c|}{$\mathrm{F}_{\mathrm{m}}$} \\
\hline Grecco a Palla & $3041.67 \mathrm{Aa}$ & 2827.00 Aab & $2773.67 \mathrm{Aa}$ & 2880.78 \\
\hline Alfavaca Basilicão & $3420.67 \mathrm{Aa}$ & $2666.67 \mathrm{Bb}$ & $3239.67 \mathrm{ABa}$ & 3109.00 \\
\hline Alfavaca Verde & $3132.33 \mathrm{Aa}$ & $3330.67 \mathrm{Aab}$ & $3436.67 \mathrm{Aa}$ & 3299.89 \\
\hline Lemoncino & $3523.67 \mathrm{Aa}$ & $3606.33 \mathrm{Aa}$ & $2908.00 \mathrm{Aa}$ & 3346.00 \\
\hline Roxo & $3102.33 \mathrm{Aa}$ & $3321.00 \mathrm{Aab}$ & $1692.67 \mathrm{Bb}$ & 2705.33 \\
\hline Mean & 3244.13 & 3150.33 & 2810.13 & \\
\hline \multicolumn{5}{|c|}{$\mathrm{F}_{\mathrm{v}}$} \\
\hline Grecco a Palla & $2329.67 \mathrm{Aa}$ & $2120.00 \mathrm{Aab}$ & $2079.67 \mathrm{Aa}$ & 2176.44 \\
\hline Alfavaca Basilicão & $2654.00 \mathrm{Aa}$ & $1865.33 \mathrm{Bb}$ & $2436.33 \mathrm{ABa}$ & 2318.55 \\
\hline Alfavaca Verde & $2373.67 \mathrm{Aa}$ & $2455.00 \mathrm{Aab}$ & $2639.67 \mathrm{Aa}$ & 2489.44 \\
\hline Lemoncino & $2700.67 \mathrm{Aa}$ & $2643.67 \mathrm{Aa}$ & $2166.33 \mathrm{Aa}$ & 2503.55 \\
\hline Roxo & $2363.00 \mathrm{Aa}$ & $2475.00 \mathrm{Aab}$ & $1278.67 \mathrm{Bb}$ & 2038.89 \\
\hline Mean & 2484.20 & 2311.80 & 2120.13 & \\
\hline \multicolumn{5}{|c|}{$\mathrm{F}_{\mathrm{v}} / \mathrm{F}_{\mathrm{m}}$} \\
\hline Grecco a Palla & 0.77 & 0.74 & 0.75 & $0.75 a$ \\
\hline Alfavaca Basilicão & 0.77 & 0.70 & 0.75 & $0.74 a$ \\
\hline Alfavaca Verde & 0.76 & 0.74 & 0.77 & $0.75 a$ \\
\hline Lemoncino & 0.77 & 0.73 & 0.74 & $0.75 a$ \\
\hline Roxo & 0.76 & 0.74 & 0.75 & $0.75 \mathrm{a}$ \\
\hline Mean & $0.76 \mathrm{a}$ & $0.73 \mathrm{~b}$ & $0.75 a b$ & \\
\hline
\end{tabular}

Means followed by the same letters, uppercase in the rows and lowercase in the columns, do not differ by Tukey test $(\mathrm{p} \leq 0.05)$

an indication that this cultivar is more sensitive to salinity (Tatagiba et al., 2014).

Regarding the maximum fluorescence, no significant difference was observed between the cultivars in the absence of $\mathrm{NaCl}$, and the average $\mathrm{F}_{\mathrm{m}}$ was $3,244.13$ electrons quantum ${ }^{-1}$. For the salinity of $3.5 \mathrm{dS} \mathrm{m}^{-1}$, the highest value of maximum fluorescence was observed in the cultivar 'Lemoncino', while 'Alfavaca Basilicão' showed the lowest $\mathrm{F}_{\mathrm{m}}$. When plants were

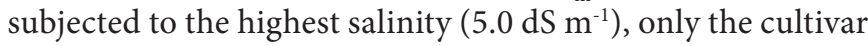
'Roxo' differed from the others, showing lower maximum fluorescence (Table 2).

The cultivar 'Alfavaca Basilicão' had a 22.04\% reduction in $\mathrm{F}_{\mathrm{m}}$ when subjected to salinity of $3.5 \mathrm{dS} \mathrm{m} \mathrm{m}^{-1}$, but showed a positive response to the highest salinity of the nutrient solution. The cultivar 'Roxo' was affected by the highest salinity $(5.0 \mathrm{dS}$

Table 1. Summary of the analysis of variance for initial fluorescence $\left(\mathrm{F}_{0}\right)$, maximum fluorescence $\left(\mathrm{F}_{\mathrm{m}}\right)$, variable fluorescence $\left(\mathrm{F}_{\mathrm{v}}\right)$, quantum efficiency of photosystem II $\left(\mathrm{F}_{\mathrm{v}} / \mathrm{F}_{\mathrm{m}}\right)$, electron transport rate (ETR), effective quantum efficiency of PSII (Y), non-regulated photochemical dissipation (YNO) and non-photochemical dissipation (YNPQ) of basil cultivars (C) subjected to different levels of nutrient solution salinity $(\mathrm{S})$

\begin{tabular}{|c|c|c|c|c|c|c|c|c|c|}
\hline \multirow{2}{*}{$\begin{array}{c}\text { Source } \\
\text { of variation }\end{array}$} & \multirow{2}{*}{ DF } & \multicolumn{8}{|c|}{ Mean squares } \\
\hline & & $F_{0}$ & $F_{m}$ & $F_{v}$ & $F_{v} / F_{m}$ & ETR & $Y$ & YNO & YNPQ \\
\hline Cultivar (C) & 4 & $49680.4^{* *}$ & $673462.1^{* *}$ & $362179.7^{*}$ & $0.000169^{n s}$ & $5922.88^{*}$ & $0.0337^{\mathrm{ns}}$ & $0.00123^{*}$ & $0.0287^{n s}$ \\
\hline Salinity (S) & 2 & $82826.9^{\star \star}$ & $782226.2^{\text {** }}$ & 497506.0* & $0.004120^{\star \star}$ & $11490.00^{* *}$ & $0.0113^{\text {ns }}$ & $0.0015^{\star}$ & $0.01723^{\text {ns }}$ \\
\hline $\mathrm{C} \times \mathrm{S}$ & 8 & $29695.9 * *$ & $648636.0^{* *}$ & $419513.3^{* *}$ & $0.000576^{\text {ns }}$ & $5760.16^{\star \star}$ & $0.0528 * *$ & $0.00089^{n s}$ & $0.04154^{*}$ \\
\hline Block & 2 & $7248.0^{\text {ns }}$ & $58050.0^{\text {ns }}$ & $739813.4^{\text {ns }}$ & $0.0012^{\text {ns }}$ & $3107.53^{\mathrm{ns}}$ & $0.014^{\mathrm{ns}}$ & $0.00018^{\mathrm{ns}}$ & $0.012^{\text {ns }}$ \\
\hline Residual & 30 & 8441.6 & 133103.2 & 100900.0 & 0.00069 & 1726.66 & 0.01404 & 0.00046 & 0.011 \\
\hline CV (\%) & & 12.04 & 11.89 & 13.78 & 3.51 & 42.12 & 22.64 & 31.18 & 25.59 \\
\hline
\end{tabular}

ns; ${ }^{*} ;{ }^{* *}$ Not significant, significant at $\mathrm{p} \leq 0.05$ and $\mathrm{p} \leq 0.01$, respectively by F test; DF - Degrees of freedom 
$\mathrm{m}^{-1}$ ), resulting in losses of $45.44 \%$ (Table 2), which indicates that there is the possibility of chlorophyll degradation due to salt stress, since it reduced initial and maximum fluorescence.

The reduction of $\mathrm{F}_{\mathrm{m}}$ in the cultivar 'Roxo' at the highest salinity is directly related to chlorophyll degradation (Baker, 2008). These results indicate that this cultivar may be less tolerant to the high electrical conductivity of the nutrient solution, which partially agrees with the results presented by Maia et al. (2017), who found that the cultivar 'Roxo' was sensitive to salinity above $4.5 \mathrm{dS} \mathrm{m}^{-1}$.

The variable fluorescence did not differ significantly between the cultivars in the solution without $\mathrm{NaCl}$, with an average value of 2484.20 electrons quantum ${ }^{-1}$. In the solution with EC of $3.5 \mathrm{dS} \mathrm{m}^{-1}$, the cultivar 'Lemoncino' had higher variable fluorescence and outperformed the cultivar 'Alfavaca Basilicão' by $41.73 \%$, although these two did not differ significantly from the others. At salinity of $5.0 \mathrm{dS} \mathrm{m}^{-1}$, only the cultivar 'Roxo' differed negatively from the others and had lower $\mathrm{F}_{\mathrm{v}}$ (Table 2).

Regarding the effect of salinity on $F_{v}$ the behavior was similar to that of $F_{m}$, with significant response only in the cultivars 'Alfavaca Basilicão' and 'Roxo'. For the cv. 'Alfavaca Basilicão', plants subjected to nutrient solution with salinity of $3.5 \mathrm{dS} \mathrm{m}^{-1}$ had the lowest value of $\mathrm{F}_{\mathrm{v}}$, resulting in a loss of $29.72 \%$ compared to the lowest salinity. The cultivar 'Roxo' showed reduction only at the highest salinity, which was equal to $45.89 \%$ in comparison to the salinity of $2.0 \mathrm{dS} \mathrm{m}^{-1}$ (Table 2).

Thus, the cultivar 'Alfavaca Basilicão' at salinity of $3.5 \mathrm{dS}$ $\mathrm{m}^{-1}$ and the cultivar 'Roxo' at salinity of $5.0 \mathrm{dS} \mathrm{m}^{-1}$ possibly showed lower capacity for $\mathrm{CO}_{2}$ assimilation. Similar behavior of reduction in $\mathrm{F}_{v}$ was observed by Oliveira et al. (2018) in cowpea plants (Vigna unguiculata) subjected to salt stress.

The mean quantum efficiency of PSII in the cultivars decreased by $3.95 \%$ at salinity of $3.5 \mathrm{dS} \mathrm{m}^{-1}$ in comparison to the mean at salinity of $2.0 \mathrm{dS} \mathrm{m}^{-1}$. However, there was an increase at salinity of $5.0 \mathrm{dS} \mathrm{m}^{-1}$, although it did not differ from the values obtained at the lowest salinity of $2.0 \mathrm{dS} \mathrm{m}^{-1}$ (Table 2).

The reduction in quantum efficiency of PSII at salinity of $3.5 \mathrm{dS} \mathrm{m}^{-1}$ probably indicates a decrease in the photochemical efficiency of PSII and a disturbance or damage to the photosynthetic apparatus (Glynn et al., 2003).

The cultivars studied did not differ significantly with respect to the electron transport rate (ETR) in the saline solutions of 2.0 and $3.5 \mathrm{dS} \mathrm{m}^{-1}$, obtaining averages of 71.01 and $126.36 \mu \mathrm{mol}$ electrons $\mathrm{m}^{-2} \mathrm{~s}^{-1}$, respectively. However, the cultivars differed in the nutrient solution of highest salinity $\left(5.0 \mathrm{dS} \mathrm{m}^{-1}\right)$, in which the cultivar 'Roxo' was superior to the others, which did not differ from one another (Table 3).

By evaluating the effect of salinity on the electron transport rate, it can be noted that there was a significant response in the cultivar 'Alfavaca Basilicão'. Initially, there was an $89.64 \%$ increase at the salinity of $3.5 \mathrm{dS} \mathrm{m}^{-1}$ compared to that of $2.0 \mathrm{dS}$ $\mathrm{m}^{-1}$. Then, there was a $59.20 \%$ decrease at the highest salinity $\left(5.0 \mathrm{dS} \mathrm{m}^{-1}\right)$, in comparison to the ETR obtained in plants subjected to the salinity level of $3.5 \mathrm{dS} \mathrm{m}^{-1}$. For the cultivar 'Roxo', ETR increased with the increase in nutrient solution salinity. The cultivars 'Grecco a Palla', 'Alfavaca Verde' and
Table 3. Electron transport rate (ETR), effective quantum efficiency of PSII (Y), non-regulated photochemical dissipation (YNO) and non-photochemical dissipation (YNPQ) in basil cultivars subjected to levels of nutrient solution salinity

\begin{tabular}{|c|c|c|c|c|}
\hline \multirow{2}{*}{ Cultivar } & \multicolumn{3}{|c|}{ Salinity } & \multirow{2}{*}{ Mean } \\
\hline & S1 & S2 & S3 & \\
\hline \multicolumn{5}{|c|}{ ETR $\left(\mu \mathrm{mol}\right.$ electrons $\left.\mathrm{m}^{-2} \mathrm{~s}^{-1}\right)$} \\
\hline Grecco a Palla & $70.73 \mathrm{Aa}$ & $118.57 \mathrm{Aa}$ & $83.07 \mathrm{Ab}$ & 90.79 \\
\hline Alfavaca Basilicão & $84.53 \mathrm{ABa}$ & $160.30 \mathrm{Aa}$ & $65.40 \mathrm{Bb}$ & 103.41 \\
\hline Alfavaca Verde & $69.33 \mathrm{Aa}$ & $102.00 \mathrm{Aa}$ & $64.73 \mathrm{Ab}$ & 78.69 \\
\hline Lemoncino & $75.63 \mathrm{Aa}$ & $108.07 \mathrm{Aa}$ & $54.83 \mathrm{Ab}$ & 79.51 \\
\hline Roxo & $54.80 \mathrm{Ba}$ & $142.87 \mathrm{Aa}$ & $224.97 \mathrm{Aa}$ & 140.88 \\
\hline Mean & 71.01 & 126.36 & 98.60 & \\
\hline \multicolumn{5}{|c|}{$\mathrm{Y}$} \\
\hline Grecco a Palla & $0.5903 \mathrm{Aa}$ & $0.5580 \mathrm{Aa}$ & $0.6603 \mathrm{Aa}$ & 0.6029 \\
\hline Alfavaca Basilicão & $0.6773 \mathrm{Aa}$ & $0.4397 \mathrm{ABa}$ & $0.2567 \mathrm{Bb}$ & 0.4579 \\
\hline Alfavaca Verde & $0.5693 \mathrm{Aa}$ & $0.5640 \mathrm{Aa}$ & $0.5813 \mathrm{Aa}$ & 0.5715 \\
\hline Lemoncino & $0.4357 \mathrm{Aba}$ & $0.3547 \mathrm{Ba}$ & $0.6593 \mathrm{Aa}$ & 0.4832 \\
\hline Roxo & $0.4563 \mathrm{Aa}$ & $0.5477 \mathrm{Aa}$ & $0.5020 \mathrm{Aab}$ & 0.50220 \\
\hline Mean & 0.5458 & 0.4928 & 0.5319 & \\
\hline \multicolumn{5}{|c|}{ YNO } \\
\hline Grecco a Palla & 0.0623 & 0.063 & 0.06 & $0.0618 a b$ \\
\hline Alfavaca Basilicão & 0.048 & 0.049 & 0.101 & $0.0661 \mathrm{ab}$ \\
\hline Alfavaca Verde & 0.059 & 0.047 & 0.065 & $0.0572 \mathrm{~b}$ \\
\hline Lemoncino & 0.073 & 0.079 & 0.061 & $0.0709 a b$ \\
\hline Roxo & 0.087 & 0.063 & 0.113 & $0.0875 \mathrm{a}$ \\
\hline Mean & $0.0658 \mathrm{~b}$ & $0.06046 \mathrm{~b}$ & $0.07986 \mathrm{a}$ & \\
\hline \multicolumn{5}{|c|}{ YNPQ } \\
\hline Grecco a Palla & $0.3467 \mathrm{Aa}$ & $0.3783 \mathrm{Aa}$ & $0.2790 \mathrm{Ab}$ & 0.3347 \\
\hline Alfavaca Basilicão & $0.2743 \mathrm{Ba}$ & $0.5110 \mathrm{Aa}$ & $0.6417 \mathrm{Aa}$ & 0.4757 \\
\hline Alfavaca Verde & $0.3707 \mathrm{Aa}$ & $0.3880 \mathrm{Aa}$ & $0.3530 \mathrm{Ab}$ & 0.3750 \\
\hline Lemoncino & $0.4903 \mathrm{Aa}$ & $0.5657 \mathrm{Aa}$ & $0.2797 \mathrm{Bb}$ & 0.4452 \\
\hline Roxo & $0.4560 \mathrm{Aa}$ & $0.3887 \mathrm{Aa}$ & $0.3850 \mathrm{Ab}$ & 0.4099 \\
\hline Mean & 0.3876 & 0.4463 & 0.3877 & \\
\hline
\end{tabular}

Means followed by the same letters, uppercase in the rows and lowercase in the columns, do not differ by Tukey test ( $\mathrm{p} \leq 0.05$ )

'Lemoncino' did not show a significant response, obtaining averages of $90.79,78.69$ and $79.51 \mu \mathrm{mol}$ electrons $\mathrm{m}^{-2} \mathrm{~s}^{-1}$, respectively (Table 3).

The cultivar 'Alfavaca Basilicão' under salinity of 3.5 dS $\mathrm{m}^{-1}$ increased its electron transport rate in favor of increasing the photosynthetic rate in order to minimize the impacts of salinity. However, when subjected to salinity of $5.0 \mathrm{dS} \mathrm{m}^{-1}$, the ETR was reduced, probably due to a higher rate of ATP consumption and reduced NADPH for $\mathrm{CO}_{2}$ assimilation, evidencing that the plants were stressed (Penella et al., 2014). However, plants subjected to high concentrations of $\mathrm{NaCl}$, from the beginning of the cycle, were able to acclimatize to salt stress, showing results similar to those of plants in the absence of salt stress (Table 3 ).

The cultivar 'Roxo' showed an increase in ETR values as the salt concentration increased (Table 3). Thus, it can be inferred that, even under conditions of high salinity, the cultivar 'Roxo' was more able to absorb water and maintain the electron transport flow for photosynthesis. Another possible explanation for the increase of ETR in this cultivar in response to the increase of salinity is the presence of anthocyanins in leaves, stem and floral tissues (purple color), which would perform a photoprotective and antioxidant function, reducing the negative effects of salt stress (Landi et al., 2014). However, it is possible that the increase in electron transport flow is related to the low levels of $\mathrm{F}_{0}, \mathrm{~F}_{\mathrm{m}}$ and $\mathrm{F}_{\mathrm{v}}$ and has the function of 
compensating for the photosynthetic activity and degradation of chlorophyll molecules, caused by salt stress.

There was no significant difference between cultivars for effective quantum efficiency of PSII at salinities of 2.0 and 3.5

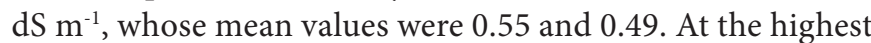
salinity $\left(5.0 \mathrm{dS} \mathrm{m}^{-1}\right)$, the highest values occurred in the cultivars 'Grecco a Palla', 'Alfavaca Verde', 'Lemoncino' and 'Roxo', although the latter did not differ from the cultivar 'Alfavaca Basilicão', which had lower values (Table 3).

Regarding the effect of salinity on the effective quantum efficiency of PSII, there was a significant response among cultivars, and the highest values were observed in the cultivars 'Alfavaca Basilicão' and 'Lemoncino'. In 'Alfavaca Basilicão', there was a reduction of $62.10 \%$ between the salinities of 2.0 and $5.0 \mathrm{dS} \mathrm{m}^{-1}$. In the cultivar 'Lemoncino', initially there was a reduction at salinity of $3.5 \mathrm{dS} \mathrm{m}^{-1}$, with a subsequent increase of $51.32 \%$ at the highest level of salinity $\left(5.0 \mathrm{dS} \mathrm{m}^{-1}\right)$ compared to the lowest salinity of $2.0 \mathrm{dS} \mathrm{m}^{-1}$ (Table 3 ).

Thus, the reductions in the effective quantum efficiency of PSII observed in the cultivars 'Alfavaca Basilicão' and 'Lemoncino' are indicative of a reduction in their photosynthetic activity, as this variables demonstrates the amount of electrons transported, indicating the occurrence of photosynthesis (Baker, 2008). Azevedo Neto et al. (2011) also reported reduction in the effective quantum efficiency of PSII in sunflower plants grown under salt stress.

For the non-regulated photochemical dissipation, only the cultivar 'Roxo' was superior to the cultivar 'Alfavaca Verde', but both did not differ from the others. In regard to the effect of salinity, in general, YNO decreased up to the salinity of 3.5 $\mathrm{dS} \mathrm{m} \mathrm{m}^{-1}$, with a subsequent increase at salinity of $5.0 \mathrm{dS} \mathrm{m} \mathrm{m}^{-1}$ (Table 3).

The increase in non-regulated photochemical dissipation with increasing salinity indicates that, in general, basil cultivars showed higher loss of energy, which may have been dissipated in an uncontrolled way in PSII, in the form of heat or through fluorescence emission (Bazihizina et al., 2015), a fact that corroborates the increase in $\mathrm{F}_{0}$ as a function of the increase in nutrient solution salinity, in all cultivars (Table 2).

These results agree with those presented by Sacramento et al. (2018), who worked with sunflower and also found that, under stress conditions, there is an increase in the parameter YNO.

For the non-photochemical dissipation (YNPQ), there was no significant difference between cultivars for salinity levels of 2.0 and $3.5 \mathrm{dS} \mathrm{m}^{-1}$, which led to averages of 0.3876 and 0.4463 ,

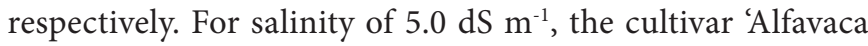
Basilicão' was superior to the others, which did not differ significantly from one another (Table 3 ).

The effects of salinity were significant only on the YNPQ of the cultivars 'Alfavaca Basilicão' and 'Lemoncino'. 'Alfavaca Basilicão' showed a $133.94 \%$ increase at the salinity of $5.0 \mathrm{dS}$

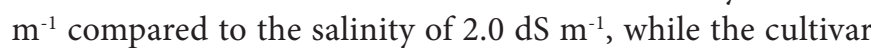
'Lemoncino' reduced its YNPQ as salinity increased, with a loss of $42.95 \%$ in plants subjected to the highest level of salinity, compared to those cultivated in the absence of $\mathrm{NaCl}$.

YNPQ refers to the dissipation of energy in the form of heat through the regulatory photoprotective mechanism (xanthophyll cycle), which prevents damage caused by excess photons, so that a high YNPQ indicates high photoprotective capacity (Sacramento et al., 2018).

Increase of YNPQ in the cultivar 'Alfavaca Basilicão' is probably a mechanism to minimize stress caused by the increase in $\mathrm{NaCl}$ concentration, which occurs through the dissipation of energy in non-photochemical processes, in the form of heat, and this result is in agreement with the reduction in the variable $\mathrm{Y}$ in the same cultivar, where light energy would be dissipated for photosynthesis. This is a strategy to protect the photosynthetic apparatus against excess energy (Li et al., 2010). On the other hand, a reduction in the value of YNPQ in the cultivar 'Lemoncino' indicates incapacity for photoprotective reactions, which may eventually cause damage to the photosynthetic apparatus (Schreiber, 2008).

In view of these results, it was found that increased salinity promotes changes in the photochemical activity of chlorophyll in basil plants. Thus, the increase in photoprotective capacity can be considered a mechanism for acclimation to salt stress.

Response to the interaction between salinity and basil cultivars was also observed by Mancarella et al. (2016), who worked with the cultivars 'Napoletano' and 'Genovese' and found no increase in YNPQ values with the increase of salinity for the cultivar 'Napoletano', while no alteration was observed for the cultivar 'Genovese'.

The cultivars 'Grecco a Palla' and 'Alfavaca Verde' had smaller changes in chlorophyll fluorescence variables under solution with high electrical conductivity $\left(5.0 \mathrm{dS} \mathrm{m}^{-1}\right)$, being considered the most tolerant cultivars to salt stress.

\section{Conclusions}

1. Basil cultivars showed different responses to the salinized nutrient solutions.

2. The photochemical efficiency of the cultivars 'Grecco a Palla' and 'Alfavaca Verde' were little affected by salinity, demonstrating that these are the most tolerant.

3. The cultivars 'Alfavaca Basilicão', 'Lemoncino' and 'Roxo' were more hampered by the salinity of $5.0 \mathrm{dS} \mathrm{m} \mathrm{m}^{-1}$.

\section{Literature Cited}

Attia, H.; Karray, N.; Ellili, A.; Msilini, N.; Lachaâl, M. Sodium transport in basil. Acta Physiologiae Plantarum, v.31, p.1045-1051, 2009. https://doi.org/10.1007/s11738-009-0324-1

Azevedo Neto, A. A.; Pereira, P. P. A.; Costa, D. P.; Santos, A. C. C. Fluorescência da clorofila como uma ferramenta possível para seleção de tolerância à salinidade em girassol. Revista Ciência Agronômica, v.42, p.893-897, 2011. http://dx.doi.org/10.1590/ S1806-66902011000400010

Baker, N. R. Chlorophyll fluorescence: A probe of photosynthesis in vivo. Annual Review of Plant Biology. v.59, p.89-113, 2008. https:// doi.org/10.1146/annurev.arplant.59.032607.092759

Bazihizina, N.; Colzi, I.; Giorni, E.; Mancuso, S.; Gonnelli, C. Photosynthesizing on metal excess: Copper differently induced changes in various photosynthetic parameters in copper tolerant and sensitive Silene paradoxa L. populations. Plant Science, v.232, p.67-76, 2015. https://doi.org/10.1016/j.plantsci.2014.12.015 
Bione, M. A. A.; Paz, V. P. S.; Silva, F.; Ribas, R. F.; Soares, T. M. Crescimento e produção de manjericão em sistema hidropônico NFT sob salinidade. Revista Brasileira de Engenharia Agrícola e Ambiental, v.18, p.1228-1234, 2014. http://dx.doi. org/10.1590/1807-1929/agriambi.v18n12p1228-1234

Dias, A. S.; Lima, G. S.; Gheyi, H. R.; Nobre, R. G.; Fernandes, P. D.; Silva, F. A. Trocas gasosas e eficiência fotoquímica do gergelim sob estresse salino e adubação com nitrato-amônio. Irriga, v.23, p.220234, 2018. http://dx.doi.org/10.15809/irriga.2018v23n2p220-234

Favorito, P. A.; Echer, M. M.; Offemann, L. C.; Schlindwein, M. D.; Colombare, L.F.; Schineider, R. P.; Hachmann, T. L. Características produtivas do manjericão (Ocimum basilicum L.) em função do espaçamento entre plantas e entre linhas. Revista Brasileira de Plantas Medicinais, v.13, p.582-586, 2011. http://dx.doi. org/10.1590/S1516-05722011000500013

Ferreira, D.F. Sisvar: A guide for its bootstrap procedures in multiple comparisons. Ciência e Agrotecnologia, v.38, p.109-112, 2014. http://dx.doi.org/10.1590/S1413-70542014000200001

Furlani, P. R.; Silveira, L. C. P.; Bolonhezi, D.; Faquin, V. Cultivo hidropônico de plantas. Campinas: Instituto Agronômico de Campinas, 1999. 52p.

Glynn, P.; Fraser, C.; Gillian, A. Foliar salt tolerance of Acer genotypes using chlorophyll fluorescence. Journal of Arboriculture, v.29, p.61-65, 2003.

IBGE - Instituto Brasileiro de Geografia e Estatística. Censo agropecuário 2017. 2018. Available on: <https://sidra.ibge.gov. br/tabela/6619\#resultado $>$. Accessed on: Jan. 2019.

Kramer, D. M.; Johnson, G.; Kiirats, O.; Edwads, G. E. New fluorescence parameters for the determination of QA redox state and excitation energy fluxes. Photosynthesis Research, v.79, p.209-218, 2004.

Landi, M.; Guidi, L.; Pardossi, A.; Tattini, M.; Gould, K. S. Photoprotection by foliar anthocyanins mitigates effects of boron toxicity in sweet basil (Ocimum basilicum). Planta, v.240, p.941953, 2014. https://doi.org/10.1007/s00425-014-2087-1

Li, G.; Wab, S.; Zhou, J.; Yang, Z.; Qin, P. Leaf chlorophyll fluorescence, hyperspectral reflectance, pigments content, malondialdehyde and proline accumulation responses of castor bean (Ricinus communis L.) seedlings to salt stress level. Industrial Crops and Products, v.31, p.13-19, 2010. https://doi.org/10.1016/j.indcrop.2009.07.015

Maia, S. S.; Silva, R. C.; Oliveira, F. D. A. D.; Silva, O. M. D. P.; Silva, A. C. D.; Candido, W. D. S. Responses of basil cultivars to irrigation water salinity. Revista Brasileira de Engenharia Agrícola e Ambiental, v.21, p.44-49, 2017. http://dx.doi.org/10.1590/18071929/agriambi.v21n1p44-49

Mancarella, S.; Orsini, F.; Oosten, M. J. van; Sanoubar, R.; Stanghellini, C.; Kondo, S.; Maggio, A. Leaf sodium accumulation facilitates salt stress adaptation and preserves photosystem functionality in salt stressed Ocimum basilicum. Environmental and Experimental Botany, v.130, p.162-173, 2016. https://doi.org/10.1016/j. envexpbot.2016.06.004

Martins, J. B.; Santos Júnior, J. A.; Silva Júnior, F. J.; Silva, G. F,; Medeiros, S. S. Production of parsley in hydroponic conditions under isosmotic brackish nutrient solutions. Ciência e Agrotecnologia, v.43, p.e023418, 2019. http://dx.doi. org/10.1590/1413-7054201943023418
Menezes, R. V.; Azevedo Neto, A. D.; Gheyi, H. R.; Cova, A. M. W.; Silva, H. H. B. Tolerance of basil genotypes to salinity. Journal of Agricultural Science, v.9, p.283-295, 2017. https:/doi. org/10.5539/jas.v9n11p283

Oliveira, W. J.; Souza, E. R.; Santos, H. R. B.; Silva, E. F. F.; Duarte, H. H. F.; Melo, D. V. M. Fluorescência da clorofila como indicador de estresse salino em feijão caupi. Revista Brasileira de Agricultura Irrigada, v.12, p.2592-2603, 2018. https://doi.org/10.7127/rbai. v12n300700

Palaretti, L. F.; Dalri, A. B.; Dantas, G. F.; Faria, R. T.; Santos, W. F.; Santos, M. G. Produtividade do manjericão (Ocimum basilicum L.) fertirrigado utilizando vinhaça concentrada. Revista Brasileira de Agricultura Irrigada, v.9, p.326-334, 2015. https://doi.org/10.7127/ rbai.v9n500326

Penella, C.; Nebauer, S. G.; Bautista, A. S.; López-Galarza, S.; Calatayud, Á. Rootstock alleviates PEG-induced water stress in grafted pepper seedlings: Physiological responses. Journal of Plant Physiology, v.171, p.842-851, 2014. https://doi.org/10.1016/j. jplph.2014.01.013

Rosas, J. T. F.; Marques Junior, E.; Lorenzoni, R. M.; Santos, F. F. L.; Martins, R. N. Effect of salinity on germination of lettuce cultivars produced in Brazil. Journal of Experimental Agriculture International, v.34, p.1-8, 2019. https://doi.org/10.9734/jeai/2019/ v34i530183

Sacramento, B. L. D.; Azevedo Neto, A. D. D.; Alves, A. T.; Moura, S. C.; Ribas, R. F. Photosynthetic parameters as physiological indicators of tolerance to cadmium stress in sunflower genotypes. Revista Caatinga, v.31, p.907-916, 2018. http://dx.doi.org/10.1590/1983$21252018 v 31 n 413 \mathrm{rc}$

Schreiber, U. Saturation pulse method for assessment of energy conversion in PS I. PPAM Application Notes, v.1, p.11-14, 2008.

Silva Júnior, F. J.; Santos Júnior, J. A.; Silva, M. M.; Silva, E. F. F.; Souza, E. R. Water relations of chives in function of salinity and circulation frequency of nutrient solutions. Revista Brasileira de Engenharia Agrícola e Ambiental, v.23, p.359-365, 2019. http:// dx.doi.org/10.1590/1807-1929/agriambi.v23n5p359-365

Silva, L. A.; Brito, M. E. B.; Sá, F. V. S.; Moreira, R. C. L.; Soares Filho, W. S.; Fernandes, P. D. Mecanismos fisiológicos em híbridos de citros sob estresse salino em cultivo hidropônico. Revista Brasileira de Engenharia Agrícola e Ambiental, v.18, p.1-7, 2014. http://dx.doi.org/10.1590/1807-1929/agriambi.v18nsupps1-s7.

Soares, H. R.; Santos Júnior, J. A.; Silva, E. F. F.; Rolim, M. M.; Silva, G. F. Water and physiological relationships of lettuce cultivated in hydroponics with brackish waters. Revista Ciência Agronômica, v.50, p.216-222, 2019. http://dx.doi. org/10.5935/1806-6690.20190025

Taibi, K.; Taibi, F.; Abderrahim, L. A; Ennajah, A.; BelkhodjA, M.; Mulet, J. M. Effect of salt stress on growth, chlorophyll content, lipid peroxidation and antioxidant defence systems in Phaseolus vulgaris L. South African Journal of Botany, v.105, p.306-312, 2016. https://doi.org/10.1016/j.sajb.2016.03.011

Tatagiba, S. D.; Moraes, G. A. B. K.; Nascimento, K. J. T.; Peloso, A. F. Limitações fotossintéticas em folhas de plantas de tomateiro submetidas a crescentes concentrações salinas. Revista Engenharia na Agricultura, v.22, p.138-149, 2014. http://dx.doi. org/10.13083/1414-3984.v22n02a05 